\title{
Estimation of potential evapotranspiration with shallow lysimeters in a forest tree nursery
}

\author{
by Jean Stein ${ }^{1}$, Richard Caissy ${ }^{2}$, André P. Plamondon ${ }^{3}$ and Pierre Y. Bernier ${ }^{4}$
}

Daily evapotranspiration values $\left(\mathrm{ET}_{\mathrm{L}}\right)$ were obtained during three consecutive summers from water balance measurements on eight shallow drainable lysimeters in similarly planted nursery beds of either white spruce [Picea glauca (Moench) Voss] or black spruce [Picea mariana (Mill) B.S.P.]. Values of $\mathrm{ET}_{\mathrm{L}}$ and of potential evapotranspiration (PET), calculated with the Penman equation, were nearly equal for most of the sampled days during the first two years. During the last year of study, the ratio $\mathrm{ET}_{\mathrm{L}} / \mathrm{PET}$ was reduced to 0.8 due to a lack of water input (precipitation and irrigation) to the lysimeters. Water balance measurements from the surrounding seedling beds showed that values of actual evapotranspiration (AET) for the first two years were 0.61 times those of either PET or $\mathrm{ET}_{\mathrm{L}}$. Rates of evapotranspiration in the lysimeters remained high because of the high water contents in the shallow lysimeters induced by the presence of a zero tension plane at the base of the lysimeters, above the drainage holes. Results indicate that well-watered shallow lysimeters can be used to estimate values of PET and be used directly for the purpose of driving water balance models for irrigation scheduling.

Key words: water relations, irrigation scheduling, lysimeters, evapotranspiration, white spruce, black spruce
Les auteurs ont obtenu l'évapotranspiration journalière $\left(E_{L}\right)$ pendant trois étés consécutifs au moyen de mesures de bilan hydrique faites sur huit lysimètres drainables et de faible profondeur placés en pépinière dans des planches similaires contenant des semis d'épinette blanche [Picea glauca (Moench) Voss] ou d'épinette noire [Picea mariana (Mill) B.S.P.]. Les valeurs d'ET L $_{\mathrm{L}}$ et d'évapotranspiration potentielle (PET), calculées selon l'équation de Penman, étaient presqu'égales pour la plupart des jours échantillonnés au cours des deux premières années. Au cours de la dernière année de l'étude, le ratio $\mathrm{ET}_{\mathrm{L}} / \mathrm{PET}$ a été réduit à 0.8 suite à une baisse d'approvisionnement en eau (précipitation et irrigation) aux lysimètres. Les mesures de bilan hydrique effectuées dans les planches environnantes indiquaient que les valeurs de l'évaporation actuelle (AET) pour les deux premières années étaient 0.61 fois supérieures aux PET ou aux $\mathrm{ET}_{\mathrm{L}}$. Les taux d'évapotranspiration dans les lysimètres sont demeurés élevés à cause de la haute teneur en eau du sol dans les lysimètres de faible profondeur induite par la présence d'une zone de tension zéro à la base des lysimètres, au dessus des trous de drainage. Les résultats indiquent que les lysimètres de faible profondeur bien approvisionnés en eau peuvent être utilisés pour estimer les valeurs de PET et pour obtenir directement les intrants nécessaires aux modèles de bilan hydrique utilisés dans la régie de l'irrigation.

\section{Introduction}

Irrigation scheduling is of critical importance in forest nurseries as seedling moisture stress can have a severe effect on growth (McDonald 1984). Many methods exist for scheduling irrigation. In container nurseries, direct weighing of the container is the most popular method for controlling irrigation scheduling (Landis 1989). In bare-root nurseries, procedures range from the subjective tactile method to more technologically demanding methods requiring the measurement of soil water tension (Prévost et al. 1989) or plant water potential. An alternative avenue is to base irrigation scheduling on water budget computations. This latter approach can also be used to predict water needs from weather forecasting. Water budget computer models are available for forest soils (Jensen et al. 1971; Mital and Sucoff 1983), and for nurseries (Rao 1987; Papadopol 1990). These models are based on the computation of potential evapotranspiration (PET) from which they obtain actual evapotranspiration (AET) through the use of a sitespecific ratio. Calculation of PET using an equation of the Penman (1948) or Rochette and Dubé (1989a, b) types require climatic

\footnotetext{
${ }^{1}$ INRS-Eau, Université du Québec, Ste-foy, Québec, Canada G1V 4C7. ${ }^{2}$ Stone Consolidated Inc., 255, lère rue, Grand-Mère, Québec, Canada G9T 5L2.

${ }^{3}$ Centre de Recherche en Biologie Forestière, Université Laval, Ste-Foy, Québec, Canada G1K 7P4.

${ }^{4}$ Canadian Forest Service, Laurentian Forestry Centre, C.P. 3800, Ste-Foy, Québec, Canada G1V 4C7.
}

data which might not be readily available at the nursery. Another disadvantage of this approach is that managers can base their decision only on calculations and thus lose contact with the soil-plant system. In order to fill this gap, the objective of this study was to evaluate the usefulness of shallow lysimeters for estimating potential evapotranspiration.

\section{Theory}

Lysimeters have been used to evaluate evapotranspiration since the end of the 18th century (Gray 1972). Brutsaert (1982) defines a lysimeter as: "a container placed in the field and filled with soil, on which a vegetation cover can be maintained for the purpose of studying various soil-water plant relationships under natural conditions". Description of common types of lysimeter can be found in Pelton (1961).

The use of any lysimeter necessarily perturbs the normal drainage pattern of the soil. Lysimeters with perforations at their base to allow for draining tend to generate a zone of zero moisture tension in the soil above the perforations. Only lysimeters which extend well below the root zone, or shallow lysimeters with suction devices at their base, can therefore give a representative evaluation of soil water content and drainage in the root zone (Tanner 1967; Ritchie and Burnett 1968; Boast and Robertson 1982). Shallow lysimeters with depths equal to or smaller than that of the root zone, without a suction device, retain more water per unit depth than the surrounding soil profile, offering more water to be transpired by plants growing in them. Since, by definition, PET is the evapotranspiration 
Table 1. Characteristics of the seedlings used in the lysimeters at the end of each season of measurements

\begin{tabular}{llcccc}
\hline Year & Species & $\begin{array}{c}\text { Height } \\
(\mathbf{c m})\end{array}$ & $\begin{array}{c}\text { Diameter }^{\mathbf{1}} \\
(\mathbf{m m})\end{array}$ & $\begin{array}{c}\text { Root }^{\mathbf{2}} \mathbf{D W}^{\mathbf{3}} \\
(\mathrm{g})\end{array}$ & $\begin{array}{c}\text { Shoot } \mathbf{D W}^{\mathbf{3}} \\
(\mathrm{g})\end{array}$ \\
\hline 1985 & Black spruce & 14.0 & 2.0 & 0.10 & 0.55 \\
1986 & Black spruce & 22.8 & 5.2 & 1.17 & 3.53 \\
1987 & White spruce & 28.2 & 5.7 & 9.36 & 9.78 \\
\hline
\end{tabular}

1: Diameter at collar height.

2: Root of all sizes.

3:DW: dry weight.

occurring when soil water is not limiting, the hypothesis of this work is that, because of their inherent ability to retain soil water, shallow well-watered lysimeters can provide direct estimates of PET.

\section{Materials and Methods}

The research site was located at the Normandin provincial forest tree nursery $\left(48.5^{\circ} \mathrm{N}, 72.3^{\circ} \mathrm{W}\right.$, altitude of $137 \mathrm{~m}$.a.s.1.), $250 \mathrm{~km}$ north-west of Québec city. Mean June, July and August precipitation is 88,105 and $75 \mathrm{~mm}$, respectively. In the same order, the average monthly air temperatures are 15,17 and $15^{\circ} \mathrm{C}$, respectively (Houde 1978). In 1985 and 1986, the study was conducted in sector 1A of the nursery, within beds of newly transplanted (one-year old) black spruce [Picea mariana (Mill.) B.S.P.] seedlings. In 1987, the study was moved to sector 1B within beds of three-year old white spruce [Picea glauca (Moench) VOSS]. The soils in sectors $1 \mathrm{~A}$ and $1 \mathrm{~B}$ are respectively a sand and a loamy sand. Morphological measurements of the seedlings during the experiment are provided (Table 1).

Eight shallow lysimeters made of plastic containers, filled with local material (sand in sector $1 \mathrm{~A}$ and sandy loam in sector 1B) and compacted to its original bulk density of about $1.0 \mathrm{~g}$ $\mathrm{cm}^{-3}$, were used during the three summers. In 1985, each lysimeter, $11 \mathrm{~cm}$ in diameter and $7.5 \mathrm{~cm}$ deep, supported three black spruce seedlings. Two bigger seedlings were planted in the larger lysimeters $(19.5 \mathrm{~cm}$ in diameter and $12 \mathrm{~cm}$ deep) used in 1986 and 1987. Root distribution measurements completed in the surrounding soil during the following year showed that only $2 \%$ of the roots extended below the depth of the larger lysimeters used in both 1986 and 1987. Small holes (4 mm) were drilled at the bottom of the lysimeters, permitting the excess water to drain freely into an outer container. The lysimeters were set into a hole, their top flush with the soil surface (Fig. 1). They were fertilized and watered as the surrounding area. The lysimeters, after removing the inner containers, were weighed daily at $08 \mathrm{~h} 00$ for the duration of the experiment. Volumes of water, if any, collected in the outer containers were then removed from the soil and measured at the same time with a graduated cylinder.

Water inputs through precipitation or irrigation were measured with rain gauges. The irrigation schedules were not modified for this study. In 1985, the rain gauges were scattered randomly within the $20 \mathrm{~m} \times 30 \mathrm{~m}$ plot in which the lysimeters were located. In 1986 and 1987, the rain gauges were placed adjacent to each one of the eight lysimeters. Water content of the soil surrounding the lysimeters was measured using time domain reflectometry (Topp et al. 1980) with $45 \mathrm{~cm}$ probes installed horizontally at depths of $7.5,12.5$ and $45 \mathrm{~cm}$ in one location. Readings were taken daily at $08 \mathrm{~h} 00$.

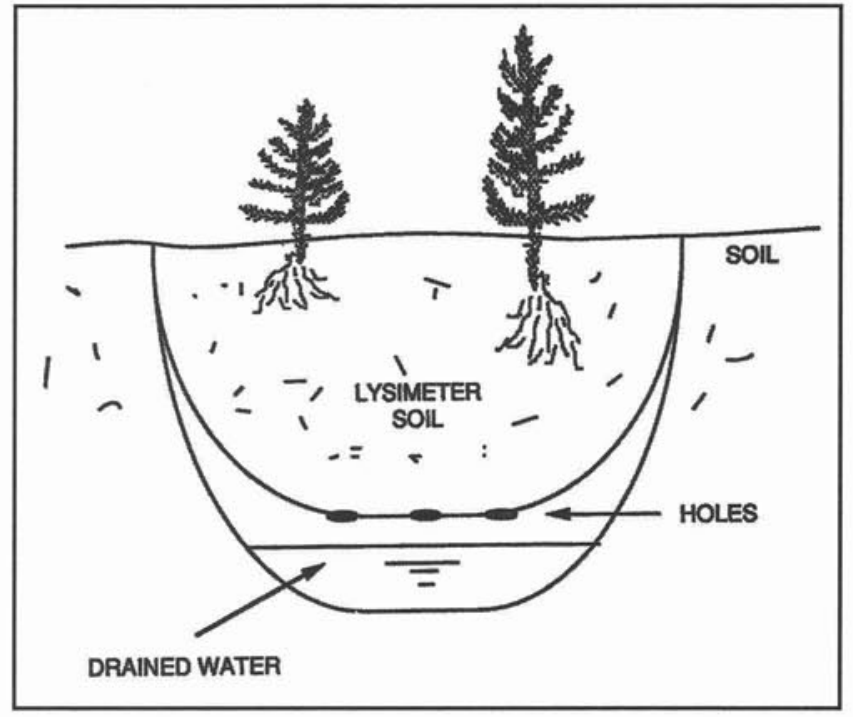

Figure 1. Lysimeter cross-section.

Daily evapotranspiration from the lysimeters $\left(\mathrm{ET}_{\mathrm{L}}\right)$, in $\mathrm{mm} \mathrm{d}^{-1}$, was determined from the soil water balance equation:

$$
E T_{\mathrm{L}}=P-D-R \pm S
$$

where $P$ is the water inputs, $D$ is the drainage from the lysimeters collected in the outer containers below the lysimeters, $R$ is the surface runoff and $\Delta S$ is the change in water storage from successive lysimeter weighing. $R$ was never observed.

Daily potential evapotranspiration (PET), in $\mathrm{mm} \mathrm{d}^{-1}$, was calculated using the Penman equation as given by Campbell (1977):

$$
P E T=\left\{s R_{\mathrm{n}}+\gamma[5.3(1+\overline{\mathrm{u}})]\left[\rho_{\mathrm{va}}{ }+\rho_{\mathrm{va}}\right]\right\} / \lambda(s+\gamma)
$$

where $s$ is the slope of the saturation vapor density curve, $R_{\mathrm{n}}$ is the daily average net radiation, $\overline{\mathrm{u}}$ is the daily average wind speed, $\rho_{\mathrm{va}}^{\prime}$ and $\rho_{\mathrm{va}}$ are the saturation and actual water vapor density of the air respectively, $\lambda$ is the latent heat of vaporization, and $\gamma$ is the psychrometric constant.

Net radiation (Swissteco, Type S-1), albedo (Weather Measure, model 3023), air temperature (thermistor, Yellow Springs Instrument Co. Inc., model 400), dew point (Weather Measure, model 8152B) and wind speed (Weather Measure, model W203-HF) were measured two meters above ground near the lysimeters. All data were integrated on a data logger at 5-minute (1985) or 30-minute (1986 and 1987) intervals during the months of June, July and August. The data were later used to compute daily averages. Failures of the recording system or of the sensors covered $7 \%$ of the experimental period. Data from the Agriculture Canada weather station of Normandin, located $11 \mathrm{~km}$ away from the nursery, were then used.

\section{Results and Discussion}

Calculations of the water budget components for the lysimeters (Table 2 ) show that the average daily change in water storage $(\Delta S)$ was usually negative during most of the experimental period. This indicates that the lysimeters were becoming gradually drier. The ratio of daily average values of $\mathrm{ET}_{\mathrm{L}}$ to PET for all months of measurements during 1985 and 1986 were nearly equal to 1.0, except June 1986, which had 
Table 2. Monthly averages of daily precipitation (P), drainage (D), change in soil water storage $(\Delta S)$ and evapotranspiration (ET $)$ in mm computed from lysimeter measurements, of daily potential evapotranspiration (PET) computed from the Penman equation (Campbell, 1977), and of the ratio of ET $_{\mathrm{L}}$ to PET.

\begin{tabular}{|c|c|c|c|c|c|c|c|c|}
\hline Year & Month & $\mathbf{P}$ & D & $\Delta \mathbf{S}$ & $\mathbf{E T}_{\mathrm{L}}$ & PET & P/PET & ET $_{\text {L }} /$ PET \\
\hline 1985 & July - August & 3.0 & 0.3 & -0.3 & 3.0 & 3.1 & 0.97 & 0.97 \\
\hline 1986 & June & 2.2 & 0.0 & -0.8 & 3.0 & 3.7 & 0.60 & 0.82 \\
\hline 1986 & July & 4.8 & 1.2 & -0.2 & 3.7 & 3.6 & 1.30 & 1.03 \\
\hline \multirow[t]{2}{*}{1986} & August & 3.6 & 1.0 & -0.5 & 3.1 & 3.0 & 1.20 & 1.04 \\
\hline & Year average & 3.6 & 0.8 & -0.5 & 3.3 & 3.4 & 1.06 & 0.97 \\
\hline 1987 & June & 3.1 & 0.2 & 0.5 & 2.4 & 3.7 & 0.84 & 0.65 \\
\hline 1987 & July & 2.4 & 0.0 & -0.9 & 3.3 & 3.5 & 0.69 & 0.94 \\
\hline \multirow[t]{2}{*}{1987} & August & 2.6 & 0.2 & 0.6 & 1.9 & 3.0 & 0.88 & 0.64 \\
\hline & Year average & 2.6 & 0.1 & -0.1 & 2.6 & 3.3 & 0.78 & 0.78 \\
\hline
\end{tabular}

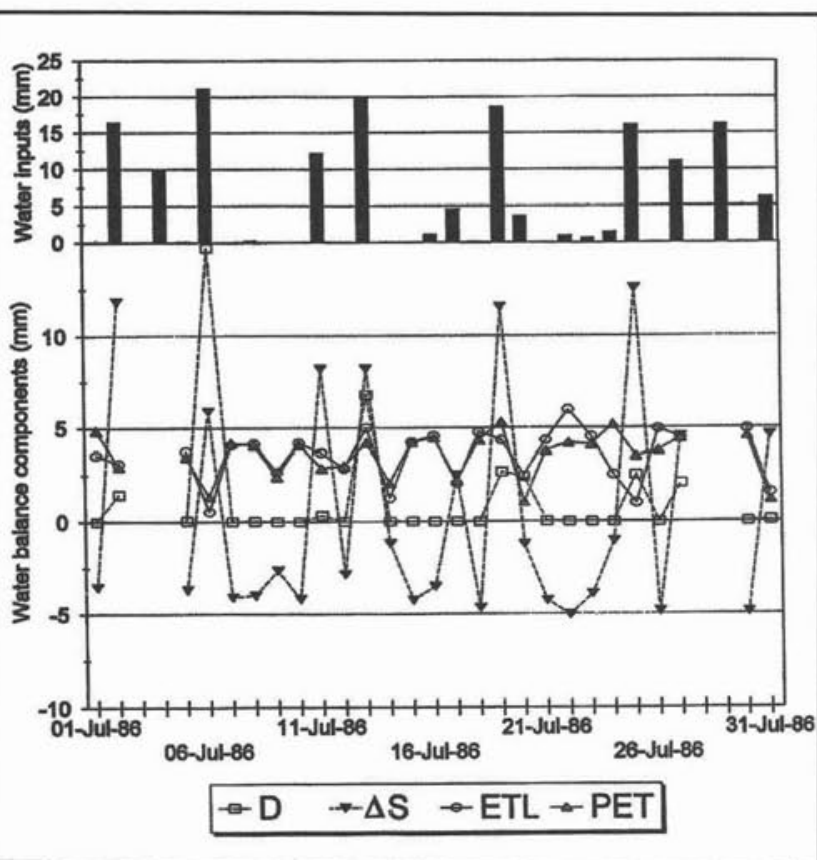

Figure 2. Daily values of precipitation (P), drainage (D), evapotranspiration $\left(\mathrm{ET}_{\mathrm{L}}\right)$, change in storage $(\Delta \mathrm{S})$ measured in the lysimeters and of potential evapotranspiration (PET) computed from the Penman equation, for the month of July 1986. All values are in $\mathrm{mm}$.

a ratio of 0.82 (Table 2) in response to a lower P/PET ratio. The potential evapotranspiration calculated with the Penman equation followed quite closely the evapotranspiration obtained from the lysimeters (Fig. 2). This result agrees with observations by Pelton (1961) and Van Bavel (1961) who also noted a close relationship between ET measured from shallow lysimeters and maximum evapotranspiration rate if a zero moisture tension plane was present at the bottom of the lysimeters. During the 1987 season, the average daily input of water to the lysimeters was not sufficient to sustain PET and this resulted in much lower values of the ratio $\mathrm{ET}_{\mathrm{L}} / \mathrm{PET}$. Whenever the monthly $\mathrm{P} / \mathrm{PET}$ was smaller than 1,0 , the ratio $\mathrm{ET}_{\mathrm{L}} / \mathrm{PET}$ was also smaller than 1.0.

As expected, the 7.5 and $12 \mathrm{~cm}$ deep lysimeters generally maintained water contents higher than those of the surrounding top soil profile following an input of water through precipitation or irrigation. In the soil column surrounding the lysimeters, water quickly infiltrated to deeper soil layers, especially given the relatively coarse texture of the soils. Once this ini-

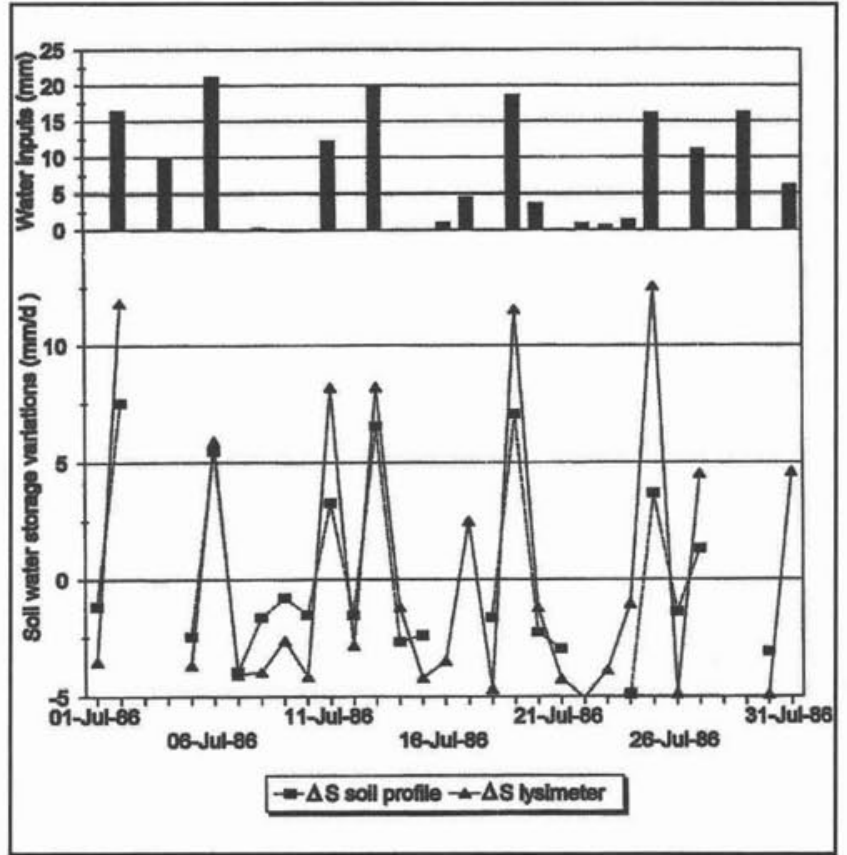

Figure 3. Daily variations in soil water dynamics $\left(\mathrm{mm} \mathrm{d}^{-1}\right)$ in the lysimeters and in the surrounding soil profile for the month of July 1986.

tial quick drainage was completed, variations in the water content of the soil in the lysimeters and in the surrounding profile was mostly due to evapotranspiration. The lysimeters showed the largest variations in soil water content during the intervals between precipitation events (Fig. 3). Greater availability of water in the lysimeters resulted in greater evapotranspiration from the lysimeters than in the surrounding beds of seedlings.

As stated earlier, water balance models that use PET also require an empirical parameter to transform PET values into AET. Prévost et al. (1989) computed such a parameter for another Québec nursery and obtained a value of 0.69 . In the present study, estimates of AET from the seedling beds were also obtained from water budget calculations during drier periods in 1987, assuming that the drainage term $(D)$ was negligible. The AET/PET ratio obtained at this site was 0.61 .

\section{Conclusion}

When kept well-watered, the evapotranspiration measured with the lysimeters corresponded to the potential evapotran- 
spiration calculated with the Penman formula. Consequently, these lysimeters overestimated the actual evapotranspiration and the soil water storage variations and underestimated the drainage when compared to natural conditions because of the presence of a zero moisture tension plane. Shallow lysimeters used in Normandin could be used to evaluate potential evapotranspiration instead of the Penman equation, thus eliminating the need for complex instrumentation to measure the climatic parameters. When combined with periodic evaluations of the soil water content, evapotranspiration measured with shallow lysimeters could be used in a model which could help in deciding the time, frequency and amount of water to be applied to bareroot seedlings in a nursery.

\section{Acknowledgements}

Thanks are extended to the personnel of the Normandin nursery for their invaluable technical help, as well as to known and anonymous reviewers for critical reviews of this manuscript. Funding for this work was provided by NSERC (Natural Sciences and Engineering Research Council) and the Quebec Ministry of Natural Resources.

\section{References}

Boast, C.W. and T.M. Robertson. 1982. A microlysimeter method for determining evaporation from bare soil: description and laboratory evaluation. J. Soil Sci. Soc. Am. 46:689-696.

Brutsaert, W. 1982. Evaporation into the atmosphere, theory, history and applications. P. Reidel Publishing Company, England. 299 p. Campbell, G.S. 1977. An introduction to environmental biophysics. Springer-Verlag, New-York. 159 p.

Gray, D.M. 1972. Manuel des principes d'hydrologie. Publication du secrétariat, Comité national canadien de la décennie d'hydrologie internationale, Ottawa, ON. 725 p.

Houde, A. 1978. Atlas Climatologique du Québec: température, précipitation Ministère des Richesses Naturelles. (Pub. M-36), 42 planches.

Jensen, M.E., J.L. Wright and B.J. Pratt. 1971. Estimating soil moisture depletion from climate, crop and soil data. Trans. ASAE 14:954-959.
Landis, T.D. 1989. Seedling nutrition and irrigation. The container tree nursery manual. Vol. 4. USDA For. Ser. Ag. Handbook $674,119 p$.

McDonald, S.E. 1984. Irrigation in forest tree nurseries: monitoring and effects on seedling growth, pp. 107-121 In Forest nursery manual: production of bareroot seedlings, M.L. Durya and T.D. Landis, eds. Martinus Nijhoff/Dr. W. Junk Publishers, The Hague/Boston/Lancaster for Forest Research Laboratory. Oregon State University, Corvallis, OR. 386 p.

Mital, D. and E. Sucoff. 1983. Predicting soil moisture depletion beneath trembling aspen. Can. J. For. Res. 13:45-52.

Papadopol, C.S. 1990. Irrigation rate calculation for nursery crops. Tree planters' Notes 41:22-27.

Pelton, W.L. 1961. The use of lysimetric methods to measure evapotranspiration. Proc. of Hydrology Symposium No 2, Evaporation Queen's Printer, Ottawa, ON. pp. 106-127. Cat. No R32-361/2.

Penman, H.L. 1948. Natural evaporation from open water, bare soil and grass. Proc. R. Soc. Lond. 193:120-145.

Prévost, M., J. Stein and A.P. Plamondon. 1989. Water balance and irrigation planning in a forest tree nursery. Can. J. For. Res. 19:575-579.

Rao, N.H. 1987. Field test of a simple soil-water balance model for irrigated areas. J. Hydrol. 91:179-186.

Rochette, P. and P.A. Dubé. 1989a. Variabilité spatiale de l'estimation de l'évapotranspiration potentielle au Québec Méridional. Nat. Can. 116:267-278.

Rochette, P. and P.A. Dubé. 1989b. Calibration d'une équation simple pour l'estimation de l'évapotranspiration potentielle au Québec Méridional. Nat. Can. 116:193-203.

Ritchie, J.T. and E. Burnett. 1968. A precision weighing lysimeter for row crop water use studies. Agron. J. 60:545-549.

Tanner, C.B. 1967. Measurement of evapotranspiration. pp. 534-574 In Irrigation of agricultural lands, R.M. Hagan, H.R. Haise and T.W. Edminister, eds. Amer. Soc. Agron. Monog. No 11, 1180 p.

Topp, G.C., J.L. Davis and A.P. Annan. 1980. Electromagnetic determination of soil water content: measurements in coaxial transmission lines. Water Resour. Res. 16:574-582.

Van Bavel, C.H.M. 1961. Lysimetric measurements of evapotranspiration rates in the eastern United States. Proc. Soil Sci. Soc. Am. 25:138-141. 